\title{
THEORIES OF SELF-PREFERENCING UNDER ARTICLE 102 TFEU: A REPLY TO BO VESTERDORF
}

\author{
Nicolas Petit*
}

\section{Introduction}

Bo Vesterdorf, the former President of the General Court ("GC") of the European Union ("EU"), has recently expressed his view on the theory of antitrust liability that he believes to be applicable in the on-going EU Commission investigation into Google with respect to online search (the "Google search case"). ${ }^{1}$ His interesting paper ("the paper") suspects the complainants of proposing a "new non-discrimination theory" whereby a dominant firm cannot "self-preference" it "own operations over those of competitors" under Article 102 of the Treaty on the Functioning of the EU ("TFEU"). ${ }^{2}$

Vesterdorf argues that the sole theory of antitrust liability applicable to the Google search case is the refusal to supply theory, better known as the "essential facilities" doctrine. In his view, no other theory of liability can prohibit a dominant firm from self-preferencing its own services over those of rivals. Vesterdorf then explains that the essential facilities doctrine is subject to such drastic conditions that it only applies in "very limited circumstances". He insists also preliminarily on the general principle that dominant firms have a right to compete "on the merits".

The paper's representation of positive law can be approached as authoritative. Vesterdorf is a former architect of the Article 102 TFEU case-law. Readers will recall that Vesterdorf was President of the GC in the 2007 Microsoft case. ${ }^{3}$ Since he left the GC, Vesterdorf has been a prolific commentator of the EU antitrust case-law. On several occasions, I have praised his lucid and pragmatic interpretations. ${ }^{4}$

But the paper's depiction of positive law is a bit disconcerting too. It scorns that dominant firms can be pursued for abusive self-preferencing under theories of liability other than essential

\footnotetext{
* Professor, University of Liege (ULg), Liege Competition and Innovation Institute ("LCII"). Nicolas.petit@ulg.ac.be. This paper has benefited from the financial support from ICOMP. ICOMP is a complainant in the ongoing EU competition proceedings against Google. See www.i-comp.org. The views expressed in this paper are entirely personal, and had been previously and publicly set out before this paper was commissioned.

${ }^{1}$ Bo Vesterdorf, Theories of Self-Preferencing and Duty to Deal - Two Sides of the Same Coin, 1(1) Competition Law \& Policy Debate, 4 (2015).

${ }^{2} I d$.

${ }^{3}$ In this capacity, he presided the hearing in the Microsoft case.

${ }^{4}$ N. Petit, Injunctions for FRAND-Pledged SEPs: The Quest for an Appropriate Test of Abuse Under Article 102 TFEU , 9 Euro. Comp. J. 677.
} 
facilities doctrine. The paper also proposes a restrictive interpretation of the scope of the essential facilities doctrine that strays from accepted scholarly consensus, and that deviates from Vesterdorf's own writings. ${ }^{5}$ Lastly, the paper pretends to recount the law as it is, yet it often digresses on the policy debate of what the law should (or not) be.

The present reply seeks to restore what I believe is the positive legal standard applicable to "theories of self-preferencing" in EU competition law. This is a subject of first importance, which takes precedence over any policy discussion on the substantive content of Article 102 TFEU (whether, for instance, it should be dominant firm-friendly or unfriendly). No policy discussion is indeed possible without a proper understanding of the positive law. Accordingly, this paper is not about what I would like the law to be, but about what (I believe) it presently is. $^{6}$

This reply successively reviews, and discusses, the three foundations on which the paper is based, ie that there cannot be a "duty not to favour" short of an essential facility (I); that there cannot be an essential facility except in "very limited circumstances" (II); and that "competition on the merits" is a general principle that immunizes dominant firm from antitrust liability (III).

\section{THEORIES OF SELF-PREFERENCING AND THE WISHFUL PREREQUISITE OF THE ESSENTIAL FACILITIES DOCTRINE}

The paper pretends that theories of abusive self-preferencing are conditioned on the applicability of the essential facility doctrine. This is untrue. A dominant firm can be found guilty of abusive self-preferencing in legal settings distinct from essential facility cases (A). And an antitrust duty of non-preference can be ordered on a dominant firm under evidentiary conditions laxer than those requested by the essential facilities doctrine (B).

\section{A. Theories of SElf-PrefERENCING OUTSIDE Essential Facilities CASES}

\footnotetext{
${ }^{5}$ Bo Vesterdorf, Article 82 EC: Where do we Stand after the Microsoft Judgement?, Global Antitrust Review, 1 (2008).

${ }^{6}$ I have, on several occasions, expressed distaste at the present state of Article 102 TFEU law, which I believe is too harsh on dominant firms. In previous papers, I have lamented the formalistic approach to dominant firm conduct, and the overly large scope of the concept of abuse under Article 102 TFEU that stems from an inconsistent, abstract, and agency-biased case-law. My inimicality for the current state of the law remains intact at the time of writing. But I feel that it does not lead me to confuse, and depict, the Article 102 TFEU law that I would like to read in lieu of the Article 102 TFEU law that currently exists.
} 
In EU competition law, there are several legal basis under which a dominant firm that selfpreferences in favor of its own operations can be found liable of an unlawful abuse. Their application can give rise to the imposition of direct or indirect duties of non-preference.

\section{Discrimination}

A straightforward legal basis for a theory of abusive self-preferencing is Article 102 (c) TFEU. This provision says that it is abusive for a dominant firm to apply "dissimilar conditions to equivalent transactions with other trading parties, thereby placing them at a competitive disadvantage". Its scope covers dominant firm discrimination that inflicts a "secondary line injury". ${ }^{7}$ This refers to situations where the dominant firm distorts the competition that takes place between its customers (or suppliers).

In the case-law, Article 102 (c) TFEU has been predominantly applied in settings where a vertically-integrated dominant firm sought to advantage its downstream operations at the expense of rivals. ${ }^{8}$ Several cases display a clear theory of abusive self-preferencing. ${ }^{9}$ Let us sift through the most glaring illustrations. In Deutsche Bahn, the Commission found, and the GC confirmed, that Transfracht, a maritime transport subsidiary of the German Railway operator, had unlawfully benefited from lower fees than its rival Intercontainer for access to the rail infrastructure. ${ }^{10}$ In GT-Link, a public undertaking that owned and operated a commercial port had exonerated its downstream ferry services from port duties, but had requested them from a rival ferry company. The CJEU held that this could constitute unlawful discrimination pursuant to Article 102 (c) TFEU. ${ }^{11}$ In ITT Promedia, the Commission closed proceedings against the Belgian telecommunications incumbent, in exchange for a commitment to also

\footnotetext{
${ }^{7}$ R. Joliet, Monopolization and Abuse of a Dominant Position - A Comparative Study of the American and European Approaches to the Control of Economic Power, Collection scientifique de la faculté de droit de l'université de Liège, Faculté de droit, Université de Liège, Martinus Nijhoff, La Haye, 1970, p.244. Professor Joliet talked of discrimination that affects "buyers' competition".

${ }^{8}$ D Gerard 'Price Discrimination under Article 82(c) EC: Clearing up the Ambiguities' in Global Competition Law Centre Research Papers on Article 82 EC - July 2005, 133; D. Geradin and N. Petit, "Price Discrimination under EC Competition Law - Another Doctrine in Search of Limiting Principles?" 2(3) Journal of Competition Law and Economics 479 (2006).

${ }^{9}$ In the $2^{\text {nd }}$ edition of their leading treatise on Article 102 (c) TFEU, O'Donoghue and Padilla, also reference discrimination by a vertically integrated dominant firm against downstream rival as the first example of abuse under Article 102 (c) TFEU. R. O'Donoghue and J. Padilla, The Law and Economics of Article 102 TFEU, $2^{\text {nd }}$ ed., Hart Publishing, 2013, p.804. In a previous study of 2007, I and my co-author also reached a similar finding.

${ }^{10} \mathrm{GC}$, Deutsche Bahn AG v Commission, T-229/94, ECR [1997] II-1689.

${ }^{11}$ CJEU, GT-Link A/S and De Danske Statsbaner (DSB), C-242/95, ECR [1997] ECRI-4449, para 41.
} 
charge its subsidiary Belgacom Directory Services ("BDS") for subscriber data (and not only independent phone directory publishers). ${ }^{12}$

On the facts, some of those cases may well have featured an essential facility. However, none of those cases was legally reasoned in essential facilities terms. Given the text of Article 102 (c) TFEU, there was no need for the Commission and/or the Courts to follow that legal avenue. In all three cases, the presence of bottleneck industries seemed at best circumstantial. ${ }^{13}$

One possible exception to this is the Commission interim relief decision Stena Sealink/B\&IHolyhead where it is stated that it is unlawful for an essential facility to discriminate in favour of its own activities in a related market. ${ }^{14}$ Does this, however, imply that dominant firm discrimination is lawful absent an essential facility? This is not what the Treaty and subsequent case-law say, and it would be giving much authority to an interim measures order which merely reached a prima facie finding of infringement. But beyond this, presenting B\&I/Stena Sealink in support of the idea that discrimination is only unlawful in essential facilities settings is preposterous. The absurdity of the argument is best captured with a metaphor: if a judge says that it is unlawful for a Professor of copyright law to plagiarize other writers, it does not imply that plagiarism is lawful from other law Professors (or more generally from other individuals).

Admittedly, Article 102 (c) TFEU cases of abusive self-preferencing are rare in EU competition law. This dearth of cases could reflect agency disbelief in the fact that Article (c) 102 TFEU constitutes a solid legal basis against the self preferencing tactics of dominant firms. But that situation could equally mirror that dominant firms understand the clear prohibition rule of Article 102 (c) TFEU, and accordingly refrain from brazen self-preference towards related companies. There is support to this hypothesis in subsequent case-law, which shows that

\footnotetext{
12 Commission Press Release, IP/97/292, Brussels, 11 April 1997, Settlement reached with Belgacom on the publication of telephone directories - ITT withdraws complaint. Whilst this last case did not give rise to a clear and definitive pronouncement of the EU courts (unlike Deutsche Bahn and GT-Link), it gives a graphic illustration of abusive self-preferencing.

${ }^{13}$ R. O'Donoghue and J. Padilla, supra p.804. Cases of actual discrimination indeed arise most frequently in the area of liberalized utilities, because incumbents subject to market opening reforms have strong incentives to exclude competitors.

${ }^{14}$ See Commission Decision of 11 June 1992, IV/34.174, Sealink/B\&I - Holyhead: Interim measures, para 41: “A dominant undertaking which both owns or controls and itself uses an essential facility, ie, a facility or infrastructure without access to which competitors cannot provide services to their customers, and which refuses its competitors access to that facility or grants access to its competitors only on terms less favourable than those which it gives its own services, thereby placing the competitors at a competitive disadvantage, infringes Article 86 [now 102] if the other conditions of that Article are met".
} 
dominant firms have disadvantaged downstream rivals through more convoluted forms of discrimination. $^{15}$

Moreover, in recent years, the Commission has not relinquished from pressing objections of abusive self-preferencing under Article 102 (c) TFEU. No later than 2008, it brought to a halt the practices of E.ON, the dominant electricity network operator, which it suspected of "favouring its own production affiliates" through preferential purchases. ${ }^{16}$

At any rate, a policy consideration cannot have the effect of reading out Article 102 (c) of the Treaty.

\section{Tying}

Theories of abusive self-preferencing can also be based on the frame of reference offered by tying law. Pursuant to Article 102 (d) TFEU, a dominant firm shall not "mak[e] the conclusion of contracts subject to acceptance by the other parties of supplementary obligations which, by their nature or according to commercial usage, have no connection with the subject of such contracts". In the conventional tying scenario, a dominant supplier of complementary goods A and $\mathrm{B}$ creates a preferential tie between A-B in order to leverage its dominant position from market A towards market B.

In the case-law, tying cases often feature the formulation of antitrust duties of non-preference. Perhaps no case shows this better than Microsoft I. In its 2004 decision, the Commission found that an abusive tie had been created through the pre-installation of Windows Media Player ("WMP") on the dominant Operating System ("OS") Windows for PC. The Commission objected that:

"Microsoft uses Windows as a distribution channel to anti-competitively ensure for itself a significant competition advantage in the media player market. Competitors, due to Microsoft's tying, are a priori at a disadvantage" ${ }^{17}$

And the General Court in 2007, chaired at the time by Vesterdorf, upheld those findings in full, holding that:

\footnotetext{
${ }^{15}$ See Commission Decision of 20 October 2004, COMP/38.745, BdKEP/Deutsche Post AG and Bundesrepublik Deutschland; Commission Decision of 2 June 2004, COMP/38.096, Clearstream; Commission Decision of 14 May 1997, IV/34.621, Irish Sugar plc.

${ }^{16}$ Commission Decision of 26 November 2008, COMP/39.388, German Wholesale Electricity Market (E.ON). To remove the "conflict of interest" diagnosed by the Commission, E.ON offered a divestiture (para 52 and 53 in particular).

${ }^{17}$ Commission Decision of 24 March 2004, COMP/C-3/37.792 Microsoft, para 979.
} 
" a supplier whose software is initially pre-installed on the client PC and is launched automatically as soon as the PC is started clearly has a competitive advantage over any other supplier of similar products". ${ }^{18}$

Similar conclusions were reached in the browser case of 2009. ${ }^{19}$ And if the remedies applied in both cases differ, both the 2004 "naked" version of Windows and the 2009 "choice screen" shared a common ambition: that of eroding the alleged preferential advantage enjoyed by Microsoft complementary software.

\section{Unfair Pricing}

Theories of abusive self-preferencing can again be framed in terms of unfair trading conditions. Article 102 (a) TFEU reputes abusive the imposition, by a dominant firm, of "unfair purchase or selling prices or other unfair trading conditions". In the case-law, this provision has indirectly been used to wear away favors unfairly granted by dominant firms to downstream subsidiaries or close-knit business partners. ${ }^{20}$ United Brands, the leading case on unfair pricing, illustrates this. ${ }^{21}$ The Commission found that the United Brands Company ("UBC") had committed an infringement of Article 102 TFEU by charging excessive prices for the bananas sold to German ripeners. Little known is that UBC had granted preferential prices to a German ripener by the name of the Scipio group, with whom it had a "close business relationship". ${ }^{22}$ It is unclear how much this favor weighted in the final determination of unfair pricing. But the Commission's finding of infringement expressly criticized the preferential treatment granted to the Scipio group. ${ }^{23}$

\footnotetext{
${ }^{18}$ GC, Microsoft v Commission, T-201/04, ECR [2007] II-03601, para 1042.

${ }^{19}$ Commission Decision of 16 December 2009, COMP/C-3/39.530, Microsoft (tying).

${ }^{20}$ In a seminal book, Professor Amato also tied the prohibition of unfair pricing to a sort of duty of non-preference: "seen as breach of competition, it ought to be an abuse insofar as it damages competition itself, which can actually happen whenever an enterprise in a dominant (or monopoly) position in ownership of networks or production of raw materials also produces services that use the network or goods that need those raw materials, in competition with others. In this case, there is abuse if by practicing high prices not linked to costs, it damages its competitors on the downstream markets, consequently strengthening itself. In this framework, the case looks like a sub-species of discriminatory practices, and thus comes under typical antitrust evaluative canons". See G. Amato, Antitrust and the Bounds of Power - The Dilemma of Liberal Democracy in the History of the Market, Hart Publishing, Oxford, 1997, p. 74.

${ }^{21}$ Commission Decision of 17 December 1975, IV/26699 - Chiquita.

${ }^{22}$ Id., para II. A. 2.: "BC treats the Scipio Group as regards the control imposed over ripening facilities and the organization of marketing in exactly the same way as it treats its own subsidiaries and the other distributor/ripeners".

${ }^{23}$ Id.: "United Brands Company has infringed Article 86 [...] by imposing unfair prices for the sale of Chiquita bananas on its customers in the Belgo-Luxembourg Economic Union, Denmark, the Netherlands and Germany (other than the Scipio Group)". At remedial stage, the Commission dissipated the price advantage enjoyed by the Scipio group. UBC was requested to reduce banana prices on all ripeners by $15 \%$, with the exception of the Scipio group.
} 
ITT Promedia was also a case advanced under Article 102 (a) TFEU. ${ }^{24}$ ITT Promedia had paid a price representing $34 \%$ of its turnover for subscriber data. The Commission objected to this, besides the discrimination charges previously discussed. ${ }^{25}$ Under the settlement with Belgacom, the dominant firm pledged to charge cost-oriented prices to ITT Promedia. This indirectly dissipated the preferential treatment granted by Belgacom to its subsidiary BDS.

\section{Other Legal Avenues}

The Article 102 case-law brings other examples of theories of abusive self-preferencing, though less explicit. ${ }^{26}$ Van den Bergh Foods is a case in point. ${ }^{27} \mathrm{HB}$, a dominant ice cream producer had provided Irish retailers with freezer cabinets free of charge. In exchange, Irish retailers had committed to exclusively store the dominant supplier ice cream in the freezer cabinets. Both the Commission and the GC found an infringement of Article 102 TFEU. The case was reasoned as a classic case of exclusive dealing. But it also featured a salient "self-preferencing" dimension. With the freezer exclusivity clause, HB exploited its proprietary control over freezer cabinets so as to favor its own products, at the expense of competitors'.

\section{Discussion}

The silence of the paper on the existence of alternative legal basis for a theory of abusive selfpreferencing is hardly a surprise. As I have explained in previous writings, those theories of liability impose lighter enforcement costs than the essential facilities case-law, while they reserve the agency discretion to apply equally intrusive remedies. ${ }^{28}$ Conceding this would have defeated the whole point of the paper on the necessary prerequisite of the essential facilities doctrine.

\section{B. Duty of Non-PREFERENCE Below the Essential FACILITIES THRESHOLD}

The paper pretends that there can be "no obligation on a dominant undertaking to treat its competitors in downstream or related markets in the same way as its own operations [...]

\footnotetext{
${ }^{24}$ Commission Press Release, IP/97/292, Brussels, 11th April 1997, Settlement reached with Belgacom on the publication of telephone directories - ITT withdraws complaint.

${ }^{25}$ It seemed to consider that there was no justification for this, except the market power associated with Belgacom's dominant position.

26 A possible example is the Commission Decision of 18 December 2013, COMP/AT.39678 and COMP/AT.39731, Deutsche Bahn I and II that relate to a margin squeeze in the traction current market, through preferential discounts, see para 23 and 24.

${ }^{27}$ GC, Van den Bergh Foods Ltd v Commission, T-65/98, [2003] ECR II-4653.

${ }^{28}$ N. Petit and N. Neyrinck, "Back to Microsoft I and II: Tying and the Art of Secret Magic", 2 Journal of European Competition Law \& Practice 117 (2011).
} 
without establishing the existence of an essential facility". ${ }^{29}$ It goes on to argue that if the dominant firm is under no duty to deal under Article 102 TFEU, the fact that it agrees to deal with its competitors in downstream or related markets cannot lead to an "additional (and even more onerous) obligation" to deal with them under conditions similar to its own services. ${ }^{30}$

In other words, a duty of non-preference is conditioned on proof that the essential facilities doctrine conditions are fulfilled. For ease of discussion, I refer to this as the essential facilities threshold.

My discomfort with the essential facility threshold is not one of logic. I have myself warned against risks of inconsistencies in the case-law: if a dominant firm can lawfully eliminate rivals by withholding supplies, how can it be guilty of abuse when it supplies them, even at unfavorable conditions? ? $^{31}$

Rather, it is one of discourse. The paper pretends to describe the law as it stands. But the essential facility threshold nowhere exists in positive law. On the contrary, the CJEU vacated that construct in TeliaSonera. ${ }^{32}$ At issue in the case was whether a margin squeeze constituted a variant of the essential facilities doctrine that ought to be subject to the Brönner conditions. ${ }^{33}$ This view had entertained some traction in academic writings. However, the TeliaSonera Court refused to follow this path. At paragraph 56 of its judgment, it held that margin squeezes are an "independent" form of abuse, "distinct" from a refusal to supply. Moreover the Court's refutation of the essential facilities threshold is not strictly confined to margin squeezes cases:

"before any conduct of a dominant undertaking in relation to its terms of trade could be regarded as abusive the conditions to be met to establish that there was a refusal to supply would in every case have to be satisfied, and that would unduly reduce the effectiveness of Article 102 TFEU', ${ }^{34}$

Since the adoption of TeliaSonera, antitrust experts have fretted over the interpretation of the judgment. A possible reading of the ruling of the CJEU in TeliaSonera is that once a dominant firm has voluntarily chosen to supply a customer, it can no longer refuse to deal, and this

\footnotetext{
${ }^{29}$ Vesterdorf Paper, supra p.9.

${ }^{30} I d$. p.7.

${ }^{31}$ N. Petit, "The Future of the Court of Justice in EU Competition Law - New Role and Responsibilities" in The Court of Justice and the Construction of Europe: Analyses and Perspectives on Sixty Years of Case-law, Court of Justice of the EU ed., Nomos Verlagsgesellschaft, 2013.

${ }^{32}$ CJEU, Konkurrensverket v TeliaSonera Sverige AB, C-52/09, [2011] ECR I-00527. I have, in a previous paper, argued that the sections of TeliaSonera in relation to positive price squeezes have been overruled by the Court judgment in PostDanmark. But the judgment's legal integrity on the concept of a margin squeeze remains intact.

${ }^{33}$ Id. See Opinion of Advocate General Mazák, 2 September 2010, para 18: "such arrangements constitute in my view a form of refusal to deal".

${ }^{34}$ Id., para 58. In the Court's own words, it is the "effectiveness" of Article 102 TFEU that dictated this solution.
} 
notwithstanding the fact that the restrictive conditions of the essential facilities doctrine may not be fulfilled. This interpretation is the one championed by certain officials of the EU Commission. Amongst them, Coates talks of an "Estoppel" abuse. ${ }^{35}$

Another possible interpretation is that any dominant firm is under a duty not to exploit clients through unfair or discriminatory terms and conditions. The TeliaSonera Court presumably had this in mind when it affirmed at paragraph 25 that margin squeezes are a "pricing practice" of the kind falling within "subparagraph (a) of the second paragraph of Article 102 TFEU [that] expressly prohibits a dominant undertaking from directly or indirectly imposing unfair prices". 36

Whichever interpretation may be right, both throw doubt on the paper's contention that a dominant firm that "is not [...] under any obligation to supply" pursuant to the essential facility threshold cannot be liable to "an additional obligation to treat its downstream or related market competitors in the same way as its own services". ${ }^{37}$ This may be the judicial interpretation that the paper would like to see adopted. But it does not represent the law as it stands.

\section{SUMMATION}

The paper's proposition that a "duty not to favour" can only be imposed on a dominant firm in circumstances where this firm controls an essential facility and refusal of access to this essential facility is abusive is not borne out by positive law. Theories of abusive self-preferencing are quite widespread in the Article 102 TFEU case-law.

Moreover, the TeliaSonera Court buried to the ground the essential facility threshold theory. Before it, the Van den Bergh Foods judgment already contained a passage that weakened the foundation of the argument. The applicant in Van den Bergh Foods had submitted that the Commission should have scrutinized the case under the essential facilities framework, and in particular under the restrictive interpretation of the doctrine proposed by Advocate General Jacobs in Brönner. ${ }^{38}$ The applicant hoped to have Article 102 TFEU declared inapplicable.

\footnotetext{
${ }^{35}$ See Coates' blog: http://www.twentyfirstcenturycompetition.com/2013/10/the-estoppel-abuse/ In his view, this reading of the judgment is appropriate because customers make commercial decisions on the basis of the offer to supply, and it would be unfair to hold them up ex post with supply-disruption threats.

${ }^{36}$ CJEU, Konkurrensverket $v$ TeliaSonera Sverige AB, C-52/09, para 25: “As regards the abusive nature of pricing practices such as those in the main proceedings, it must be noted that subparagraph (a) of the second paragraph of Article 102 TFEU expressly prohibits a dominant undertaking from directly or indirectly imposing unfair prices".

${ }^{37}$ Vesterdorf Paper, supra p.7.

${ }^{38}$ GC, Van den Bergh Foods Ltd v Commission, T-65/98, para 148.
} 
The GC rejected this contention, and confirmed the Commission's discretion over the selection of a theory of liability in Article 102 TFEU cases. ${ }^{39}$ This, together with TeliaSonera, strongly suggests that the essential facilities prerequisite advanced by the paper is wishful thinking.

More generally, the paper draws a rigid connection between the antitrust remedy - here, a duty of non-preference - and the antitrust theory of liability - here, the essential facilities doctrine. This idea, as interesting as it may be, is discredited by the law. The Commission can design either behavioral or structural remedies in antitrust cases, subject to effectiveness and proportionality principles. This remedial freedom is best proof of the absence of a strict nexus between the remedy and the theory of liability in antitrust cases.

\section{THE DISINGENUOUS DESCRIPTION OF THE ESSENTIAL FACILITIES DOCTRINE}

The paper is right to insist that it is a demanding task to establish an essential facility in positive law. But it is certainly not the mission impossible that it depicts.

\section{A. 2008 v 2015}

Having attempted to present theories of self-preferencing as the second "side" of refusal to deal cases, the paper moves on to paint a grim picture of the essential facilities doctrine. The argument goes that the doctrine is subject to strict case-law conditions, and thus applies only in "very limited circumstances". ${ }^{40}$ This is because the CJEU has allegedly adopted a "narrow definition" of an essential facility. ${ }^{41}$

Readers familiar with earlier Vesterdorf's papers will recall his 2008 article on the Microsoft judgment. ${ }^{42}$ The text garnered a lot of attention. In a somewhat unusual confession, Vesterdorf regretted that the Microsoft judgment handed down by his Court had not been brought on appeal before the upper EU Court.

The 2008 prose also contained an interesting discussion of the implications of Microsoft on the licensing of intellectual property rights ("IP") case-law, and more generally on the refusal to supply case-law. ${ }^{43}$ Let us recall the main conclusion of the paper:

\footnotetext{
${ }^{39}$ Id., para 161. The GC held that the "reference to the Opinion of Advocate General Jacobs in the judgment in Brönner, is irrelevant in the present case".

${ }^{40}$ Vesterdorf Paper, supra p.6.

${ }^{41}$ Vesterdorf Paper, supra p.7.

${ }^{42}$ Bo Vesterdorf, "Article 82 EC: Where do we stand after the Microsoft judgment", (2008) Global Antitrust Review, 1.

${ }^{43} I d$., p.4.
} 
"According to some views, with this judgment, the weaponry of competition authorities in general and the European Commission in particular has been reinforced [...] There can be relatively broad agreement that the judgment may have far reaching consequences. [...] The European Commission and the national competition authorities of Member States will now have support for a more powerful intervention vis-à-vis dominant undertakings, which may be good for competition [...] (emphasis added)"

Commenting on the various conditions of an unlawful refusal to supply, Vesterdorf reached a similar diagnosis. On the "indispensability" condition, he noted that the GC's acceptance of the Commission's approach in Microsoft:

"probably makes it easier to find a refusal on the part of dominant undertaking abusive"

And in relation to the "elimination of competition" condition, he observed that the:

"shift from elimination of all to elimination of effective competition appears to have at the same time rendered the conditions for finding an infringement of Article 82 EC less strict by loosening the conditions for finding an abuse in these situations. To most people this shift is probably wellfounded, as what is necessary is that there is room for some effective and not just some, however toothless, competition".

The 2008 and the 2015 papers thus seem worlds apart in terms of their reading of the refusal to supply case-law. Besides all the questions this begets, the author's manifest change in opinion justifies casting a critical, uncompromising eye on the 2015 text. This is what I do in the next sessions.

\section{B. Positive IRRELEVANCE OF MicRosofT?}

The overture of Vesterdorf's discussion of the essential facilities doctrine starts with a qualification of the Microsoft judgment. ${ }^{44}$ To recall the context, Microsoft had marked a "broadening" the essential facilities doctrine. ${ }^{45}$ The Microsoft Court indeed relaxed the restrictive "new product" condition set by the Court in Magill and IMS Health to establish an abusive refusal to license IPRs. ${ }^{46}$ It held that a determination of abuse had to be based on the open-ended Treaty text of Article 102 (b) TFEU, which talks of a limitation of "technical development" ${ }^{47}$

\footnotetext{
${ }^{44}$ Again, for sake of transparency, I have to recall here that I have criticized elsewhere the Microsoft judgment on prospective and consequential grounds. But this does not mean that I consider that the Microsoft judgment is not positive law.

${ }^{45}$ Bo Vesterdorf, "Article 82 EC: Where do we stand after the Microsoft judgment", supra p.9.

${ }^{46}$ CJEU, Radio Telefis Eireann (RTE) and Independent Television Publications Ltd (ITP) v Commission (Magill), Case C-241/91 P and C-242/91, [1995] 743; CJEU, IMS Health, GmbH \& Co. OHG v NDC Health GmbH \& Co. $K G$, Case C-418/01, [2004] I-5039.

${ }^{47} \mathrm{GC}$, Microsoft v Commission, T-201/04, para 647. The GC held: 'The circumstance relating to the appearance of a new product, as envisaged in Magill and IMS Health... cannot be the only parameter which determines whether a refusal to license an intellectual property right is capable of causing prejudice to consumers within the
} 
Understandably, Microsoft is unsupportive of the paper's whole point that the essential facilities doctrine has a narrow scope. Vesterdorf thus advances the following consideration to defuse the relevance of Microsoft. Even if Article 102 (b) TFEU generally prohibits all conduct that limits technical development, it is:

"in [his] opinion clear that if negative effects on competitors are only due to the dominant company providing something extra to consumers, which draws these to it [...] there this cannot be contrary to Article 102 (b)". ${ }^{48}$

This novel idea has no foundation in positive law. Neither the Treaty, nor subsequent case-law, have ever referred to this. But even under a policy perspective, the proposed qualification is untenable. What the paper suggests is the introduction of an ancillary restraints theory in Article 102 TFEU. According to it, the restrictive effects of a refusal to supply on competitors ought to be ignored as ancillary if they arise in the context where a dominant firm offers some additional product, feature or enhancement to consumers and/or it does so without charging any additional price. Even with this final condition, this ancillary restraint theory is patently improper. It would excuse restrictions of competition on one side of a dominant platform, as soon as an additional service would be given to users on the other side of the platform, possibly for free (for instance, a search engine). We would end up with a regime of Article 102 TFEU immunity for all dominant two-sided platforms. This cannot be the law. Moreover, this does not correspond to the framework of analysis of two-sided markets introduced by the CJEU in Cartes Bancaires and Mastercard under Article 101 TFEU. ${ }^{49}$

To close, readers will notice that at the end of President Vesterdorf's paper, Microsoft appears again. This time it is invoked as a relevant precedent, in support of the argument. By now, however, it should be apparent that the paper's reading of Microsoft cannot safely be trusted.

\section{INCOMPLETE ACCOUNT OF THE INDISPENSABILITY TEST?}

The paper hammers that "a product or service will only constitute an essential facility in very limited circumstances". The argument is based on Brönner, which defines an essential facility

meaning of Article 82(b) EC. As that provision states, such prejudice may arise where there is a limitation not only of production or markets, but also of technical development.'

${ }^{48}$ Vesterdorf Paper, supra p.6.

${ }^{49}$ CJUE, Groupement des cartes bancaires v Commission, C-67/13 P, 11 September 2014, not yet published; CJEU, MasterCard Inc. v Commission, Case C-382/12 P, 11 September 2014, not yet published. For further discussion, see D. Auer and N. Petit, "Two-Sided Markets and the Challenge of Turning Economic Theory into Competition Policy" (January 20, 2015). Available at SSRN: http://ssrn.com/abstract=2552337 or http://dx.doi.org/10.2139/ssrn.2552337. 
in terms of "indispensability". ${ }^{0}$ The Brönner indispensability test has two prongs. First, the facility in question will only be deemed indispensable if there is no alternative to it, ${ }^{51}$ including a "less advantageous" one. ${ }^{52}$ This is the substitutability prong of the indispensability test. Second, the facility will only be deemed indispensable "if it is not economically viable to create a second" system. ${ }^{53}$ This is the replicability prong of the indispensability test.

The paper proceeds to apply the indispensability test to the facts underpinning the Google search case. At best, this discussion is selective. The paper focuses on the substitutability prong of the Brönner test, stressing the alleged existence of many alternative "routes to market" to Google's search engine for the distribution of specialized (or vertical) search results. In contrast, the paper stays mute on the question whether it would be "economically viable" (for "any undertaking" in the words of Advocate General Jacobs) to replicate Google's search engine.

This approach can conceivably be justified if the second prong of the test is subsidiary. But this leaves out of account the case-law subsequent to Brönner, which suggests that the brunt of the indispensability analyzis has to be conducted under the replicability prong, and that the substitutability prong occupies a marginal role in the assessment. Microsoft, again, is the leading case on this issue. In the judgment, the GC repudiated the substitutability evidence adduced by the dominant firm that several existing software products allowed a degree of interoperability with Windows for servers, and that reverse engineering was possible. The GC ruled that the key question in the indispensability test was the "economic viability" of rival companies. ${ }^{54}$ Other essential facilities cases also confirm the predominance of the replicability prong in the indispensability test. ${ }^{55}$ In European Night Services, for instance, the General Court

\footnotetext{
${ }^{50}$ CJEU, Brönner v Mediaprint, C-7/97 [1998] ECR I-817. I agree with Vesterdorf that Brönner is a relevant precedent in a search engine context. The case was about a newspaper distribution infrastructure, much like a search engine is an information distribution platform.

${ }^{51}$ Vesterdorf writes "no actual or potential substitute for that service".

${ }^{52}$ CJEU, Brönner v Mediaprint, C-7/97, supra para 43.

${ }^{53}$ Id., para 46. According to Advocate General Jacobs, at para 66 of his Opinion under Brönner, "the test [...] must be an objective one". The replicability must be "uneconomic" for "any other undertaking". See Opinion of Advocate General Jacobs delivered on 28 May 1998, C-7/97 [1998] ECR I -7794.

${ }^{54}$ Bo Vesterdorf, "Article 82 EC: Where do we stand after the Microsoft judgment", supra p.7.

${ }_{55}$ Communication from the Commission - Guidance on the Commission's enforcement priorities in applying Article 82 of the EC Treaty to abusive exclusionary conduct by dominant undertakings, OJ C 45, 24.2.2009, p.720: "In general, an input is likely to be impossible to replicate when it involves a natural monopoly due to scale or scope economies, where there are strong network effects or when it concerns so-called 'single source, information. However, in all cases account should be taken of the dynamic nature of the industry and, in particular whether or not market power can rapidly dissipate".
} 
insisted on "the prohibitive cost of and/or time reasonably required for reproducing". ${ }^{56}$ In IMS Health, the CJEU stressed that the "the degree of participation by users in the development of that structure" could affect replication costs. ${ }^{57}$

\section{Elimination of All EFFECtive COMPETITION IN CONTEXT}

The dangers of discussing law in a vacuum are well-known. And lack of context is precisely the main flaw of the paper in relation to the "elimination of competition" condition.

The paper starts by recalling that the essential facilities doctrine requires proof that the refusal to deal is likely to eliminate "all effective competition" on a downstream or related market. ${ }^{58}$ Microsoft is aptly pointed as the authority for this condition. ${ }^{59}$ The paper then asserts that if competitors have other potential routes to market, or are already using such routes, then it is "clear that all effective competition is not eliminated". ${ }^{60}$ On the facts, the paper claims that vertical search websites have various means to bypass Google's platform.

I do not intend to discuss here whether Google is, on the facts, a gatekeeper for online search and search advertising services. Instead, I would like to redress a possible misrepresentation of the "elimination of all effective competition" condition.

Paragraph 563 of the Microsoft judgment speaks for itself:

"Nor is it necessary to demonstrate that all competition on the market would be eliminated. What matters, for the purpose of establishing an infringement of Article 82 EC, is that the refusal at issue is liable to, or is likely to, eliminate all effective competition on the market. It must be made clear that the fact that the competitors of the dominant undertaking retain a marginal presence in certain niches on the market cannot suffice to substantiate the existence of such competition (emphasis added)".

The Microsoft Court explains here that the Commission does not need proof that all market competition is harmed to find an abuse (and that the injury to competition can be potential). This statement responds to earlier developments of the case-law which had inhibited the applicability of the essential facilities doctrine. In Magill and IMS Health, the CJEU had imposed a tough standard of abuse on the Commission, holding that a refusal to supply would only be deemed unlawful if it led to the "elimination of all competition" in a secondary market.

\footnotetext{
${ }^{56}$ GC, European Night Services v Commission, T-374/94, T-375/94, T-384/94 et T-388/94, [1998] ECR II-3141, para 209.

${ }^{57}$ CJEU, IMS Health, GmbH \& Co. OHG v NDC Health GmbH \& Co. KG, Case C-418/01, para 29.

${ }^{58}$ Vesterdorf Paper, supra p.8

${ }^{59}$ Id., previously citing Brönner, which talked of "elimination of all competition".

${ }^{60} I d$., p.8.
} 
The demanding Magill-IMS Health standard required proof of the exclusion of all rivals from the market, including marginal and fringe players.

With the Microsoft test, the survival of marginal and fringe players no longer precludes the Commission from applying the essential facilities doctrine. This was acknowledged by the 2008 paper:

"this shift from elimination of all to elimination of effective competition appears to have at the same time rendered the conditions for finding an infringement of Article 82 EC [now 102 TFEU] less strict by loosening the conditions for finding an abuse in these situations". ${ }^{61}$

Of course, Magill, IMS-Health and Microsoft could be dismissed as irrelevant in the present discussion on the ground that they are IP-related cases. But this would shift us back to the caselaw on refusal to give access to physical facilities. And this case-law enshrines an even loser version of the "elimination of all competition" condition. According to it, it is not requested to bring evidence of a sick market with zero competition to apply the essential facility doctrine. Suffice is to establish that a competitor that seeks access to the facility is harmed. In Commercial Solvents, the Court talked of "eliminating all competition on the part of this customer (emphasis added)", implying that there could be an abuse even if there remained a degree of competition. ${ }^{62}$ Even more remarkably, in Brönner, the Court stressed that what mattered was the "elimination of all competition" in the market "on the part of the person requesting the service (emphasis added)". 63

\section{COMPETITION ON THE MERITS IN RESCUE}

The paper's discussion of the concept of "competition on the merits" is perhaps the least objectionable in positive law terms. ${ }^{64}$ But this is normal, because the concept of competition on the merits is essentially a policy slogan, with little normative content.

The paper argues that Article 102 TFEU incorporates a "right" of dominant firms to "compete on the merits". This entails a right to compete on "marketing efforts". And this encompasses

\footnotetext{
${ }^{61}$ Bo Vesterdorf, “Article 82 EC: Where do we stand after the Microsoft judgment", supra p.8.

${ }^{62}$ CJEU, Istituto Chemioterapico Italiano and Commercial Solvents v Commission, 6/73 and 7/73, 6 March 1974, ECR [1974] 223, para 25.

${ }^{63}$ CJEU, Brönner v Mediaprint, C-7/97, supra para 41.

${ }^{64}$ A 2005 OECD document said that competition on the merits is a popular but vague term. It added that: "Lawyers, judges and competition law enforcement officials have been using this phrase for many years to explain and justify their arguments and decisions, but there is no consensus on what the term means". OECD, Competition on the Merits, DAF/COMP(2005)27, 30 March 2006. In the same sense, see R. O'Donoghue and J. Padilla, supra p.218 (talking too of a "vague" concept).
} 
the further right, for a dominant firm, to preferentially "adverti[se], dis[play] or promo[te]" its products.

This interpretation of "competition on the merits" as a source of rights and opportunities for the dominant firm is a disputable reading of the case-law. Although this is a subtle nuance, the CJEU appears to have systematically construed "competition on the merits" as a concept that defines where Article 102 TFEU liability starts, not as a notion that says where Article 102 TFEU immunity commences. Since $A K Z O$, the standard formulation retained is: "Article 102 TFEU prohibits a dominant firm from eliminating a competitor by using methods other than those which come within the scope of competition on the merits (emphasis added)" ${ }^{65}$

The outcome of the cases where the concept of "competition on the merits" appeared confirms this. In AKZO, France Télécom, Michelin I and II, Irish Sugar and Hoffmann-La Roche, the dominant firm was found guilty of abuse. ${ }^{66}$ In none of those cases did "competition on the merits" protect the dominant firm from Article 102 TFEU liability. ${ }^{67}$

Lastly, even if competition on the merits was to be understood as a source of rights, nothing would justify to restrict those rights to the dominant firm. Put differently, the freedom to compete on the merits is as much that of the dominant firm, than that of its competitors. The Commission made this point in Van den Bergh Foods, explaining that its decision was

\footnotetext{
${ }^{65}$ CJEU, AKZO v Commission, C-62/86, [1991] ECR I-3359, para 70 ; CJEU, France Telecom, C-202/07 P [2009] ECR I-2369, para 106. Both cases talk of competition on quality, but the French version of the judgments mentioned "concurrence par les mérites". In the scholarship, both concepts are used as synonyms. In earlier cases, the Court used the expression "normal competition". See CJEU, Nv Nederlandsche banden industrie Michelin v Commission, 322/81, ECR [1983] 3461, para 70; CJEU, Hoffmann-La Roche \& Co. AG v. Commission, 85/76, ECR [1979] 461, para 91. In GC, Irish Sugar v Commission, T-228/97 Irish Sugar v Commission [1999] ECR II-2969, para 111, the General Court endorsed the concept of competition of the merits. It held that: "Article 86 of the Treaty prohibits a dominant undertaking from eliminating a competitor and thereby reinforcing its position by having recourse to means other than those within the scope of competition on the merits". In GC, Manufacture Française des pneumatiques Michelin v. Commission, T-203/01, [2003] ECRII-4071, para 97 the Court said again that: "An undertaking in a dominant position cannot have recourse to means other than those within the scope of competition on the merits".

${ }^{66}$ The fact that in some of those cases, the Court annulled part of the Commission's decision does not seem to invalidate the essence of the argument.

${ }^{67}$ Moreover, the sole justifiability defense accepted to date by the CJEU in Article 102 TFEU is that enunciated in Post Danmark. CJEU, Post Danmark A/S v Konkurrencerådet, C-209/10, [2012] ECLI:EU:C:2012:172, para 42: "it is for the dominant undertaking to show that the efficiency gains likely to result from the conduct under consideration counteract any likely negative effects on competition and consumer welfare in the affected markets, that those gains have been, or are likely to be, brought about as a result of that conduct, that such conduct is necessary for the achievement of those gains in efficiency and that it does not eliminate effective competition, by removing all or most existing sources of actual or potential competition”. See also Case T-286/09, Intel Corp. v European Commission [2014] not yet reported, para 94.This defense is modelled on the one that previously appeared in the Guidance Paper, which itself drew inspiration of the exception clause of Article 101(3) TFEU. See Guidance Paper, supra para 28-30.
} 
"intended to restore the commercial freedom of retailers and so allow rival producers to compete on the merits of their products". ${ }^{6}$

\section{Conclusion}

I have two difficulties with the article penned by Bo Vesterdorf. The first is the tendency of the paper to present as positive law what belongs to policy discourse. In my view, one should not confuse the law as it is, with the law that one wishes to be adopted. I have, myself, harshly criticized the Court's TeliaSonera judgment, on grounds of inconsistency and illogicality. But despite my dislike for this judgment, I have not expunged my writings on Article 102 TFEU from references to TeliaSonera. Neither have I denied that it is a precedent with positive value. $^{69}$

Of worse nature is, in my view, the second defect. The paper contradicts Bo Vesterdorf's own writings of 2008, without even citing them. That one's views evolve with time is normal. That changes in opinion are not publicly disclosed, acknowledged and reasoned is more surprising.

Of course, both this reply and Bo Vesterdorf's paper could be challenged on the ground that they were commissioned by private organizations which are stakeholders in the Google search case. The fact that research is financed by private donors is, however, unobjectionable as such. In many areas of social sciences, private funding is a norm. ${ }^{70}$ This happens to such a point that universities are today ranked based on their ability to attract private funding. In the antitrust field, laureates of Nobel prizes, including French economist Jean Tirole, have benefited from private funding in the context of their research. ${ }^{71}$

To steer clear of possible objections, private funded-research must fulfill two cumulative conditions. First, funding must be disclosed. Second, "but for" private funding - for instance, under public funding or without funding - the authors' research output should have been the same, and this should be verifiable. As far as I am concerned, I believe both conditions, and in particular, the second are verified. Long before this study was ordered, I had already taken public positions to the effect that the Google search case was strong, and that the case-law

\footnotetext{
${ }^{68}$ GC, Van den Bergh Foods Ltd v Commission, T-65/98, supra para 63. A similar argument was ventured in Microsoft, in support of the Commission's analyzis. GC, Microsoft v Commission, T-201/04, supra para 1046. I am grateful to J. Marcos Ramos for pointing this to my attention.

${ }^{69}$ Supra, note 31.

${ }^{70}$ It solves an opportunity cost problem.

${ }^{71}$ See, for instance, http://idei.fr/doc/wp/2014/wp_idei_803_v3.pdf
} 
offered precedential authority to apply Article 102 TFEU. ${ }^{72}$ Seeing no compelling reason in the law to change minds, I enthusiastically accepted to write the present reply to Mr. Vesterdorf.

$72 \mathrm{http} / /$ chillingcompetition.com/2012/12/13/antitrust-clone-or-why-the-google-case-is-stronger-than-themicrosoft-case/. I even went as far as writing that this case was an "antitrust clone", a "rerun" of the Microsoft tying cases. Of course, in a previous post, I had expressed pessimism over other aspects of the Google case. But this post was about another angle of the case, ie that related to allegations of abusive exploitation of the YouTube service. See http://chillingcompetition.com/2011/04/01/microsoft-v-google-\%E2\%80\%93-clash-of-the-titans/ 